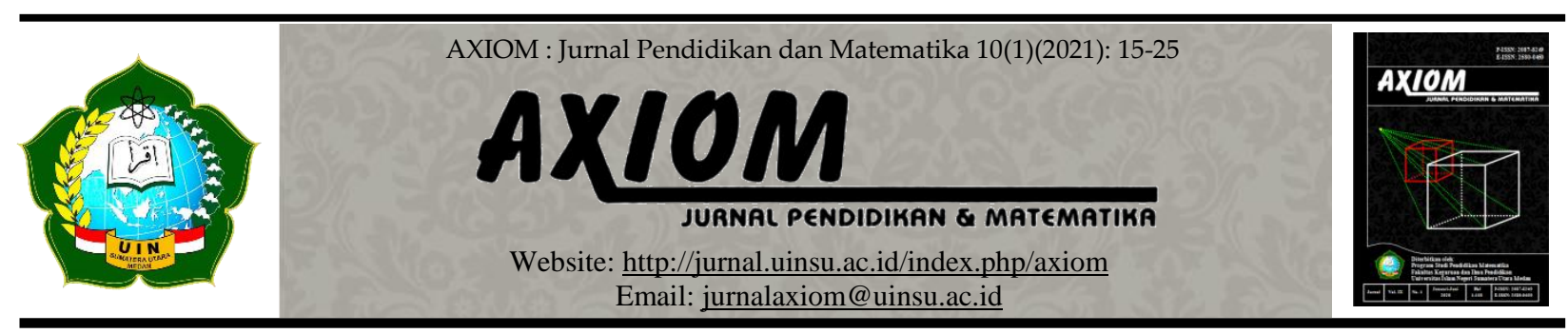

\title{
ANALISIS KESALAHAN DALAM MENYELESAIKAN SOAL MATEMATIKA MATERI PELUANG EMPIRIK DAN TEORETIK PADA SISWA KELAS VIII SMP DI KABUPATEN SIAK
}

Oleh:

\author{
Fitria Angela ${ }^{1}$, Kartini ${ }^{2}$ \\ ${ }^{1}$ Program Pascasarjana Pendidikan Matematika, Fakultas Keguruan dan Ilmu Pendidikan, \\ Universitas Riau \\ ${ }^{2}$ Program Pascasarjana Pendidikan Matematika, Fakultas Keguruan dan Ilmu Pendidikan, \\ Universitas Riau \\ E-mail: ${ }^{1}$ fitria.angela7955@grad.unri.ac.id, ${ }^{2}$ kartini@lecturer.unri.ac.id
}

doi : 10.30821/axiom.v10i1.7692

\begin{abstract}
Abstrak:
Penelitian ini bertujuan untuk mendeskripsikan kesalahan siswa dalam menyelesaikan soal cerita materi peluang empirik dan teoretik pada kelas VIII SMP Nur Hidayah di Kabupaten Siak. Jenis penelitian ini adalah deskriptif kualitatif. Subjek penelitian ini diambil dari kelas VIII SMP Nur Hidayah di Kabupaten Siak tahun ajaran 2019/2020 sebanyak sebelas siswa. Metode pengumpulan data yang digunakan dalam penelitian ini adalah tes soal cerita materi peluang empirik dan teoretik. Hasil penelitian ini menujukkan bahwa kesalahan-kesalahan yang dilakukan siswa dalam menyelesaikan soal cerita materi peluang empirik dan teoretik: (1) Kesalahan dalam membaca soal sebesar 15,15\%; (2) Kesalahan dalam memahami makna soal sebesar 12,12\%; (3) Kesalahan dalam memilih transformasi sebesar 12,12\%; (4) Kesalahan dalam proses pengerjaan 1,52\%; (5) Kesalahan dalam penulisan jawaban akhir sebesar 1,52\%.
\end{abstract}

\section{Kata Kunci:}

Analisis, Kesalahan Siswa, Soal Cerita, Peluang Empirik dan Teoretik

\section{Abstract:}

This study aims to describe the errors of students in completing questions about the material empirical and theoretical opportunities in class VIII Nur Hidayah Islamic Middle School Siak. This type of research is descriptive qualitative. The subjects of this study were drawn from class VIII of Nur Hidayah Siak Middle School in the 2019/2020 school year as many as eleven students. Data collection methods used in this study were test questions about the material empirical and theoretical opportunities. The results of this study show that the mistakes made by students in solving empirical and theoretical opportunity material story problems: (1) Errors in reading questions by $15.15 \%$; (2) Error in understanding the meaning of the questions is $12.12 \%$; (3) Errors in choosing transformation of $12.12 \%$; (4) Error in the process of 1.52\%; (5) Error in writing the final answer is $1.52 \%$.

\section{Keywords:}

Analysis, Student Mistakes, Story Questions, Empirical and Theoretical Opportunities 


\section{A. Pendahuluan}

Pendidikan matematika adalah pengetahuan dasar yang penting dan digunakan secara luas dalam kehidupan sehari-hari. Melalui pembelajaran matematika siswa diharapkan mampu menumbuhkan kemampuan dalam berpikir kritis, logis, sistematis, cermat, efektif, dan efisien dalam memecahkan masalah. Dalam pemecahan masalah diperlukan penguasaan materi dan konsep dalam belajar matematika serta kemampuan pemahaman soal dalam matematika.

Salah satu cabang matematika yang cukup penting di samping beberapa cabang ilmu matematika lainnya adalah peluang. Salah satu materi dalam mata pelajaran matematika yang dipelajari siswa pada tingkat Sekolah Menengah Pertama (SMP) adalah materi peluang teoritik dan peluang empirik. Materi ini perlu dikuasai oleh siswa SMP karena terdapat materi lanjutan mengenai peluang yang akan dipelajari di tingkat Sekolah Menengah Atas (SMA).

Masalah yang perlu diperhatikan dalam matematika adalah banyaknya kesalahan siswa dalam menyelesaikan soal-soal matematika. Menurut Wilda (2019) kesalahan yang dilakukan siswa dalam matematika perlu dianalisis sehingga hasil analisis ini dapat digunakan guru sebagai dasar untuk memberikan bantuan yang tepat. Proses ini sering disebut dengan analisis kesalahan. Kesalahan-kesalahan umum yang sering dilakukan siswa dalam menyelesaikan soal-soal matematika diantaranya adalah kesalahan membaca soal, kesalahan dalam memahami konsep matematika, kesalahan dalam menggunakan rumus matematika, kesalahan hitung, kesalahan dalam memahami simbol dan tanda, kesalahan dalam memilih dan menggunakan prosedur penyelesaian, dan kesalahan penulisan jawaban akhir. Oleh karena itu, untuk memahami konsep dalam matematika perlu memperhatikan konsep-konsep sebelumnya.

Terdapat beberapa penelitian tentang analisis kesalahan berdasarkan teori Newman, diantarannya penelitian yang dilakukan oleh Sari, Ferdiani, dan Yuwono (2018) yang bertujuan untuk menganalisis jenis kesalahan yang dilakukan oleh siswa dalam memecahkan masalah linier programming berdasarkan teori Newman. Selain itu, terdapat penelitian yang dilakukan oleh Kurnia dan Yuspriati (2020) yang bertujuan untuk mengetahui kesalahankesalahan siswa dalam menyelesaikan soal aritmatika sosial berdasarkan teori Newman serta faktor penyebabnya. Berdasarkan uraian tersebut, maka peneliti tertarik melakukan penelitian untuk mengidentifikasi kesalahan-kesalahan yang dilakukan siswa dalam menyelesaikan soal peluang empirik dan teoretik.

\section{B. Kajian Teoritis}

\section{Kesalahan dalam Meyelesaikan Soal}

Dalam kamus Bahasa Indonesia kesalahan diartikan sebagai kekeliruan atau kealpaan. Kekeliruan atau kealpaan dalam hal ini bisa dilakukan dengan sengaja ataupun tidak. Kesalahan ini timbul karena dipengaruhi oleh banyak unsur-unsur, seperti siswa itu sendiri, pengajar, metode pembelajaran, dan lingkungannya. Misalnya siswa dalam proses pembelajaran tidak memperhatikan saat guru menjelaskan dan tidak mengulang materi yang telah diberikan guru. Sehingga saat mengerjakan soal yang diberikan guru, siswa tidak bisa menyelesaikannya. Adapun kesalahan yang dilakukan pengajar misalnya jarang hadir di kelas, hanya memberikan tugas kepada siswa, sehingga bagi beberapa siswa saat diberikan soal tidak dapat menyelesaikannya. Metode pembelajaran pun berpengaruh, jika hanya melibatkan guru saja tanpa melibatkan keaktifan siswa dalam proses belajar dapat menimbulkan kejenuhan bagi siswa. Lingkukan yang ada di sekitar sekolah ataupun di sekitar siswa baik keluarga dan masyarakat sekitar sudah tentu berpengaruh terhadap siswa. Siswa yang tinggal di lingkungan yang mengerti akan pentingnya pendidikan akan berbeda dengan siswa yang berada di lingkungan yang kurang mengerti pentingnya pendidikan. Maka dari itu dalam pembelajaran, seorang guru sebaiknya melakukan analisis terhadap kesalahan yang dilakukan oleh siswa. Analisis yang dilakukan berupa mencari tahu jenis dan penyebab kesalahan siswa. Namun dalam penelitian ini peneliti hanya menganalisis kesalahan yang dilakukan siswa dalam mengerjakan soal matematika materi peluang empirik dan teoretik. 
Manibuy, Mardiyana, dan Saputro (2014) menyatakan bahwa letak kesalahan didefinisikan sebagai bagian dari penyelesaian soal yang terjadi penyimpangan. Masalah yang perlu diperhatikan dalam matematika adalah banyaknya kesalahan siswa dalam menyelesaikan soal-soal matematika. Kesalahan-kesalahan umum yang sering dilakukan siswa dalam menyelesaikan soal-soal matematika diantaranya adalah kesalahan membaca soal, kesalahan dalam memahami konsep matematika, kesalahan dalam menggunakan rumus matematika, kesalahan hitung, kesalahan dalam memahami simbol dan tanda, kesalahan dalam memilih dan menggunakan prosedur penyelesaian, dan kesalahan penulisan jawaban akhir.

Menurut Soedjadi dalam Hidayatul (2017) jenis-jenis kesalahan dalam menyelesaikan soal matematika yaitu: (1) kesalahan fakta, terjadi apabila siswa tidak dapat menuliskan dengan benar apa yang diketahui dan ditanyakan dalam soal, (2) kesalahan konsep, apabila siswa tidak dapat memahami dengan benar apa yang ditanyakan dalam soal, (3) kesalahan prinsip, yaitu ketika siswa mengetahui rumus atau aturan yang berlaku tetapi siswa tidak menggunakan rumus atau aturan tersebut saat menjawab soal, (4) kesalahan operasi, apabila siswa tidak tepat dalam menghitung hasil operasi dalam soal. Pendapat lain mengenai jenis-jenis kesalahan umum yang dilakukan siswa dalam menyelesaikan soal-soal matematika adalah menurut pendapat Rosita dalam Hidayatul (2017) yaitu: (1) kesalahan konsep, merupakan kesalahan dalam memahami gagasan abstrak. Kesalahan konsep dalam matematika berakibat lemahnya penguasaan materi secara utuh dalam matematika, aturan mempunyai makna yang sama dengan prinsip yang berupa dalil, hukum dan aturan atau rumus-rumus yang berlaku dalam mencari penyelesaian soal-soal matematika, (2) kesalahan dalam menggunakan data, seperti tidak menggunakan data yang seharusnya dipakai, salah dalam menstubstitusikan data ke variabel atau menambah data yang tidak diperlukan dalam menjawab suatu masalah, (3) kesalahan interpretasi bahasa, adalah kesalahan mengubah informasi ke ungkapan matematika atau kesalahan dalam memberi makna suatu ungkapan matematika, (4) kesalahan teknis, yaitu ketika siswa memilih jalan yang tidak tepat yang mengarah ke jalan buntu atau dapat berupa ketidaktahuan siswa dalam memilih prosedur yang tepat untuk menyelesaikan operasi-operasi yang ada, (5) kesalahan penarikan kesimpulan, yaitu melakukan kesimpulan tanpa alasan pendukung yang benar atau melakukan penyimpulan pernyataan yang tidak sesuai dengan penalaran logis. Selain itu, Menurut Newman dalam Darminto (2019) terdapat lima tahapan analisis untuk melihat kesalahan seseorang dalam menyelesaikan soal matematika yaitu tahap membaca, tahap memahami, tahap transformasi, tahap keterampilan proses, dan tahap penulisan jawaban.

\section{Teori Newman}

Metode analisis kesalahan Newman diperkenalkan pertama kali pada tahun 1977 oleh Anne Newman, seorang guru bidang studi matematika di Australia. Menurut teori Newman dalam Mulyani dan Muhtadi (2019) kesalahan dalam mengerjakan soal matematika terdiri dari 5 tipe yaitu (1) kesalahan membaca (reading error), terjadi karena siswa salah dalam mengartikan soal, tidak membaca informasi secara menyeluruh, tidak menggunakan informasi dalam soal serta tidak sesuai dengan apa yang dimaksud oleh soal, (2) kesalahan memahami (comprehention error), kesalahan ini terjadi karena siswa kurang paham terhadap konsep, selain itu siswa tidak mengetahui apa yang diketahui dan ditanyakan dalam soal serta salah menangkap informasi dalam soal sehingga siswa tidak dapat menyelesaikan permasalahan yang diberikan, (3) kesalahan transformasi (transformation error), penyebab kesalahan ini terjadi karena siswa tidak dapat mengubah soal ke dalam model matematika serta salah dalam menggunakan tanda operasi hitung, (4) kesalahan keterampilan proses (process skill error) yaitu kesalahan yang terjadi karena siswa belum terampil dalam melakukan proses perhitungan, (5) kesalahan pada notasi atau penarikan kesimpulan (encoding error), merupakan kesalahan yang terjadi pada tahap penyelesaian masalah.

\section{Soal Cerita}


Masalah-masalah dalam matematika biasanya berbentuk soal cerita. Soal cerita adalah suatu soal yang dikaitkan dengan kehidupan sehari-hari. Pada umumnya, pengerjaan soal cerita dinyatakan dalam bentuk uraian. Soal cerita merupakan salah satu tes yang dipergunakan untuk mengukur kemampuan siswa yang dapat berfungsi untuk melacak daya pikir atau nalar siswa dalam mengorganisasi, menginterprestasi, menghubungkan pengertian-pengertian yang dimiliki siswa (Sutisna, 2010).

Menurut Budiyono dalam Rokhimah (2015) soal cerita merupakan salah satu bentuk soal yang menyajikan permasalahan dalam kehidupan sehari-hari dalam bentuk narasi atau cerita. Soal cerita biasanya diwujudkan dalam kalimat yang di dalamnya terdapat persoalan atau permasalahan yang penyelesaiannya menggunakan keterampilan berhitung. Menurut Lia dalam Wibowo (2013) bahwa soal cerita dalam matematika adalah soal yang disajikan dalam bentuk kalimat sehari-hari dan umumnya merupakan aplikasi dari konsep matematika yang dipelajari. Soal cerita mempunyai karakteristik: (a) Soal dalam bentuk ini merupakan suatu uraian yang memuat beberapa konsep matematika sehingga siswa ditugaskan untuk merinci konsep-konsep yang terkandung dalam soal tersebut. (b) Umumnya uraian soal merupakan aplikasi konsep matematika dalam kehidupan sehari-hari/keadaan nyata/real world, sehingga siswa seakan-akan menghadapi kenyataan yang sebenarnya. (c) Siswa dituntut menguasai materi tes dan bisa mengungkapkannya dalam bahasa tulisan yang baik dan benar. (d) Baik untuk menarik hubungan antara pengetahuan yang telah dimiliki siswa dengan materi yang sedang dipikirkannya.

\section{Metode Penelitian}

Jenis penelitian ini adalah deskriptif kualitatif. Analisis penelitian ini menggunakan jenis prosedur kesalahan Newman yang meliputi kesalahan dalam membaca soal, kesalahan dalam memahami makna soal, kesalahan memilih transformasi, kesalahan proses perhitungan, dan kesalahan dalam penulisan jawaban akhir. Pengumpulan data dalam penelitian ini dilakukan dengan menggunakan tes. Tes esai yang diberikan kepada siswa sebanyak 6 butir soal. Penetapan subjek dalam penelitian ini berdasarkan hasil tes soal cerita materi peluang empirik dan teoretik. Subjek penelitian ini diambil dari kelas VIII SMP Nur Hidayah di Kabupaten Siak tahun ajaran 2019/2020 sebanyak sebelas siswa. Intrumen penelitian yang dipakai dalam penelitian ini adalah tes tertulis. Siswa diberikan soal sebanyak 6 soal cerita yang diberikan pada tanggal 14 April 2020 dan dikerjakan dengan sistem online yaitu peneliti meminta guru memberikan soal kepada siswa melalui aplikasi whatsapp dalam waktu 24 jam dan jawaban siswa di foto kemudian dikirim kepada peneliti. Siswa mengerjakan soal dalam bentuk uraian.

\section{Hasil Penelitian dan Pembahasan}

\section{Hasil}

Hasil analisis dari soal yang diujicoba berdasarkan validitas soal, daya pembeda soal, tingkat kesukaran soal, dan rekapitulasi soal dapat dilihat pada Tabel 1, Tabel 2, Tabel 3, dan Tabel 4.

Tabel 1. Hasil Validitas Soal

\begin{tabular}{cccccc}
\hline No. Item & $\mathbf{r}$ & $\mathbf{t}_{\text {hitung }}$ & $\mathbf{t}_{\text {tabel }}$ & Kriteria & Ket \\
\hline 1 & 0,47121 & 3,20546 & 1,85955 & Sedang & Valid \\
2 & 0,4663 & 3,16307 & 1,85955 & Sedang & Valid \\
3 & 0,57596 & 4,22732 & 1,85955 & Sedang & Valid \\
4 & 0,54385 & 3,88843 & 1,85955 & Sedang & Valid \\
5 & 0,46984 & 3,19346 & 1,85955 & Sedang & Valid \\
6 & 0,78769 & 7,67150 & 1,85955 & Sedang & Valid \\
\hline
\end{tabular}


Tabel 2. Daya Pembeda Soal

\begin{tabular}{ccc}
\hline No. Soal & Daya Pembeda & Kriteria \\
\hline 1 & 0,48 & Baik \\
2 & 0,30 & Cukup \\
3 & 0,46 & Baik \\
4 & 0,33 & Cukup \\
5 & 0,33 & Cukup \\
6 & 0,68 & Baik \\
\hline
\end{tabular}

Tabel 3. Tingkat Kesukaran Soal

\begin{tabular}{ccc}
\hline No. Soal & Tingkat Kesukaran & Kriteria \\
\hline 1 & 0,58 & Sedang \\
2 & 0,65 & Sedang \\
3 & 0,45 & Sedang \\
4 & 0,57 & Sedang \\
5 & 0,50 & Sedang \\
6 & 0,46 & Sedang \\
\hline
\end{tabular}

Tabel 4. Rekapitulasi Soal

\begin{tabular}{cccccc}
\hline $\begin{array}{c}\text { No. } \\
\text { Butir } \\
\text { Soal }\end{array}$ & Validitas & Reliabilitas & $\begin{array}{c}\text { Tingkat } \\
\text { Kesukaran }\end{array}$ & Daya Beda & Keterangan \\
\hline 1 & Valid & Tinggi & Sedang & Baik & digunakan \\
2 & Valid & & Sedang & Cukup & digunakan \\
3 & Valid & & Sedang & Baik & digunakan \\
4 & Valid & & Sedang & Cukup & digunakan \\
5 & Valid & & Sedang & Cukup & digunakan \\
6 & Valid & & Sedang & Sedang & digunakan \\
\hline
\end{tabular}

Berdasarkan tabel yang telah disajikan, maka diperoleh kesimpulan bahwa soal nomor 1, 2, 3, 4, 5 dan 6 layak digunakan untuk menganalisis kesalahan siswa berdasarkan prosedur kesalahan Newman yang terdapat 5 indikator kesalahan. Indikator tersebut antara lain kesalahan dalam membaca soal, kesalahan memahami makna soal, kesalahan memilih transformasi, kesalahan proses hitung, dan kesalahan dalam penulisan jawaban akhir. Pemilihan subjek dilakukan berdasarkan banyaknya kesalahan siswa dalam menyelesaikan soal cerita materi peluang. Dapat dilihat pada Tabel 5.

Dengan melihat Tabel 5, dapat terlihat bahwa pada soal nomor 1 sebanyak 1 siswa, nomor 2 sebanyak 1 siswa, nomor 4 sebanyak 3 siswa, nomor 5 sebanyak 2 siswa dan nomor 6 sebanyak 3 siswa kesulitan pada tahap membaca, dalam hal ini siswa belum mampu memaknai kalimat yang mereka baca dengan tepat. Pada tahap pemahaman sebanyak 8 siswa tidak memahami soal nomor 6 , mereka tidak dapat memahami apa yang diketahui dan ditanyakan dalam soal dengan baik. Sedangkan pada tahap transformasi pada soal nomor 3 sebanyak 1 siswa, nomor 4 sebanyak 6 siswa dan nomor 5 sebanyak 1 siswa tidak mampu mentransformasi kalimat matematika dalam soal cerita tersebut. Pada tahap keterampilan proses hanya 1 siswa yang melakukan kesalahan pada soal nomor 4. Sedangkan pada tahap penulisan jawaban akhir hanya 1 siswa yang melakukan kesalahan dalam penulisan jawaban akhir yaitu pada soal nomor 4. 
Tabel 5. Jenis Kesalahan Siswa

\begin{tabular}{ccccccc}
\hline \multirow{2}{*}{$\begin{array}{c}\text { Nomor } \\
\text { Siswa }\end{array}$} & \multicolumn{2}{c}{ Indikator 1 } & \multicolumn{2}{c}{ Indikator 2 } & \multicolumn{2}{c}{ Indikator 3 } \\
\cline { 2 - 6 } & $\begin{array}{c}\text { Soal } \\
\text { Nomor 1 }\end{array}$ & $\begin{array}{c}\text { Soal } \\
\text { Nomor 2 }\end{array}$ & $\begin{array}{c}\text { Soal } \\
\text { Nomor 3 }\end{array}$ & $\begin{array}{c}\text { Soal } \\
\text { Nomor 4 }\end{array}$ & $\begin{array}{c}\text { Soal } \\
\text { Nomor 5 }\end{array}$ & $\begin{array}{c}\text { Soal } \\
\text { Nomor 6 6 }\end{array}$ \\
\hline 1 & & & & $\mathrm{E}$ & & $\mathrm{B}$ \\
2 & & & $\mathrm{~A}$ & & $\mathrm{~B}$ \\
3 & & $\mathrm{C}$ & $\mathrm{C}$ & & $\mathrm{B}$ \\
4 & & $\mathrm{D}$ & $\mathrm{C}$ & & $\mathrm{B}$ \\
5 & & $\mathrm{~A}$ & $\mathrm{C}$ & $\mathrm{A}$ & $\mathrm{B}$ \\
6 & & & $\mathrm{~A}$ & $\mathrm{~A}$ & $\mathrm{~A}$ \\
7 & & & & & $\mathrm{~A}$ \\
8 & & & $\mathrm{~A}$ & $\mathrm{C}$ & $\mathrm{A}$ \\
9 & $\mathrm{~A}$ & & $\mathrm{C}$ & $\mathrm{C}$ & $\mathrm{B}$ \\
10 & & & $\mathrm{C}$ & & $\mathrm{B}$ \\
11 & & & $\mathrm{C}$ & & $\mathrm{B}$ \\
\hline
\end{tabular}

Catatan:
A: Kesalahan membaca
B: Kesalahan pemahaman
C: Kesalahan transformasi
D: Kesalahan proses
E: Kesalahan penulisan jawaban

Berikut ini adalah hasil penelitian, diperoleh presentase kesalahan yang paling banyak dilakukan oleh siswa.

Tabel 6. Persentase Jenis Kesalahan Siswa

\begin{tabular}{|c|c|c|c|c|c|c|}
\hline Indikator & Soal & $\begin{array}{l}\text { Kesalahan } \\
\text { Membaca }\end{array}$ & $\begin{array}{l}\text { Kesalahan } \\
\text { Pemahaman }\end{array}$ & $\begin{array}{l}\text { Kesalahan } \\
\text { Transormasi }\end{array}$ & $\begin{array}{c}\text { Kesalahan } \\
\text { Proses }\end{array}$ & $\begin{array}{c}\text { Kesalahan } \\
\text { Penulisan } \\
\text { Jawaban } \\
\text { Akhir }\end{array}$ \\
\hline \multirow[t]{2}{*}{1} & 1 & 1 & 0 & 0 & 0 & 0 \\
\hline & 2 & 1 & 0 & 0 & 0 & 0 \\
\hline \multirow[t]{2}{*}{2} & 3 & 0 & 0 & 1 & 1 & 0 \\
\hline & 4 & 3 & 0 & 6 & 0 & 1 \\
\hline \multirow[t]{2}{*}{3} & 5 & 2 & 0 & 0 & 1 & 0 \\
\hline & 6 & 3 & 8 & 1 & 0 & 0 \\
\hline \multicolumn{2}{|c|}{ Total } & 10 & 8 & 8 & 1 & 1 \\
\hline \multicolumn{2}{|c|}{ Persentase } & $(15,15 \%)$ & $(12,12 \%)$ & $(12,12 \%)$ & $(1,52 \%)$ & $(1,52 \%)$ \\
\hline \multicolumn{2}{|c|}{ Kategori } & $\begin{array}{l}\text { Sangat } \\
\text { Rendah }\end{array}$ & $\begin{array}{l}\text { Sangat } \\
\text { Rendah }\end{array}$ & $\begin{array}{l}\text { Sangat } \\
\text { Rendah }\end{array}$ & $\begin{array}{l}\text { Sangat } \\
\text { Rendah }\end{array}$ & $\begin{array}{l}\text { Sangat } \\
\text { Rendah }\end{array}$ \\
\hline
\end{tabular}

Berdasarkan Tabel 6 dapat dilihat bahwa siswa yang melakukan kesalahan dalam membaca sebanyak 15,15\%, yang melakukan kesalahan dalam pemahan sebanyak 12,12\%, kesalahan dalam transformasi sebanyak $12,12 \%$, kesalahan dalam proses perhitungan sebanyak $1,52 \%$, dan kesalahan dalam penulisan jawaban akhir sebanyak $1,52 \%$. Secara umum siswa sudah bisa menyelesaikan soal-soal yang diberikan dengan baik dan benar. Terlihat dari hasil yang didapat bahwa kesalaha siswa dikategorikan sangat rendah. Karena soal diberikan dengan sistem online dan diberikan waktu satu hari untuk mengerjakannya karena siswa juga mendapat tugas mengerjakan tugas lain yang diberikan gurunya selama tidak tatap muka disekolah dan 
belajar secara online. Namun ada beberapa soal yang tidak bisa siswa jawab dengan sempurna dan salah dalam pengerjaannya.

\section{Pembahasan}

Berdasarkan hasil tes siswa kelas VIII SMP Islam Nur Hidayah di Kabupaten Siak diperoleh data tentang kesalahan-kesalahan yang dilakukan oleh siswa dalam menyelesaikan soal cerita materi peluang empirik dan teoretik serta faktor penyebabnya dapat dilihat sebagai berikut.

\section{a. Kesalahan Membaca (Reading Error)}

Dari pengumpulan data yang telah diperoleh terlihat bahwa masih ada siswa yang bingung dalam memahami soal, terlihat dalam hasil pekerjaan siswa. Ketika tidak bisa memahami soal untuk dituliskan diketahui paling tidak siswa bisa menuliskan kembali soalnya. Kesalahan seperti ini berdasarkan prosedur Newman yaitu : 1) siswa tidak mampu membaca atau mengenal simbol-simbol dalam soal, 2) siswa tidak mampu memaknai arti kata, istilah atau simbol dalam soal. Misal contoh pekerjaan siswa di bawah ini.

\section{Soal No. 6}

Dalam sebuah pelambungan dadu sebanyak 120 kali, tercatat muncul mata dadu 5 sebanyak 18 kali dan muncul mata dadu 6 sebanyak 22 kali.

a. Tuliskan peluang teoretik dari kejadian tersebut.

b. Tuliskan peluang empirik dari kejadian tersebut.

c. Tuliskan hubungan antara peluang teoretik dengan pelang empirik.

Jawaban siswa pada soal nomer 6 dapat dilihat pada gambar 1 .

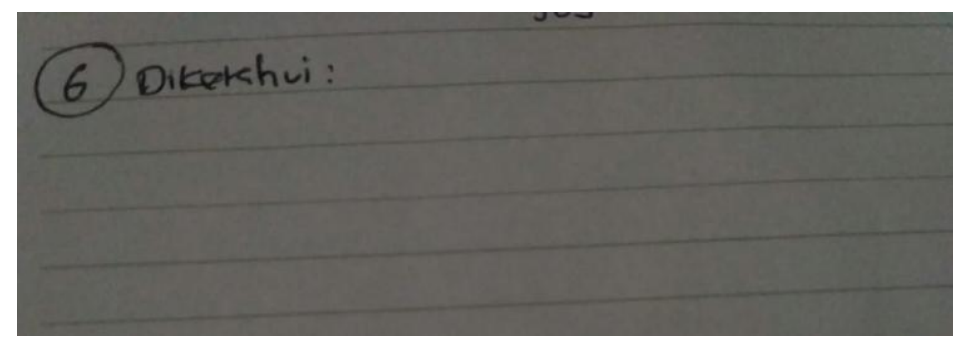

Gambar 1. Hasil Pekerjaan S1

Dari hasil pekerjaan S1 dapat dilihat bahwa S1 tidak bisa membaca soal cerita materi peluang. Dalam hal ini siswa tidak apa itu peluang, maka dari itu siswa tidak bisa mengerjakan soal tersebut.

\section{b. Kesalahan Memahami (Comprehension Error)}

Kesalahan dalam memahami makna soal yaitu siswa tidak dapat memahami maksud dari soal sehingga siswa tidak mampu melangkah lebih lanjut lagi. Dalam memahami soal, letak kesalahan siswa dapat diamati ketika ia mengerjakan soal tidak sesuai dengan apa yang ditanyakan dalam soal. Misal contoh pekerjaan siswa di bawah ini.

\section{Soal No.4}

Dalam sebuah permainan monopoli, 3 pemain menggunakan 2 dadu yang dilempar sekaligus. setiap pemain melempar dadu sebanyak 30 kali. Tentukanlah frekuensi harapan munculnya mata dadu kembar.

Jawaban siswa pada soal nomor 4 dapat dilihat pada gambar 2 


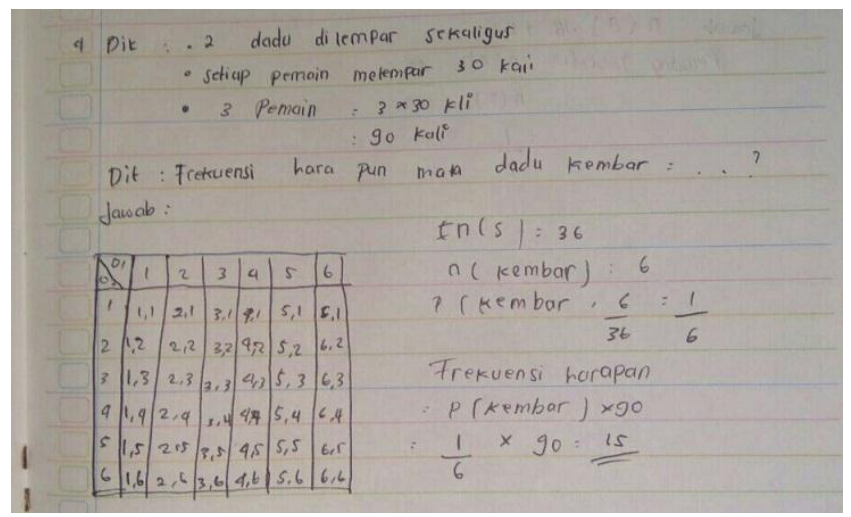

Gambar 2. Hasil Pekerjaan S2

Dalam hal ini siswa sudah mengetahui mata dadu kembar dalam dua buah mata dadu yang dilempar sekaligus. Akan tetapi dalam pekerjaan S2 terdapat kesalahan yaitu mengalikan 30 dengan 3 karena ada 3 pemain. Seharusnya siswa tidak perlu mengalikan dengan tiga karena 30 kali melempar dadu tersebut berlaku untuk semua pemain, bukan masing-masing 30 kali. Oleh karena itu, pemahaman terhadap makna soal dari awal pekerjaan sangatlah dibutuhkan dan penting sebab apabila tidak benar dapat menyebabkan kesalahan-kesalahan lain pada pekerjaan selanjutnya sehingga sangat perlu diperhatikan. Berdasarkan hasil analisis pekerjaan S2, dapat dilihat bahwa S2 belum memahami makna soal nomor 4.

\section{c. Kesalahan Transformasi (Transformation Errors)}

Kesalahan transformasi adalah siswa mampu memahami apa yang menjadi pertanyaan tetapi tidak mampu untuk mengidentifikasi operasi atau urutan operasi yang diperlukan dalam memecahkan masalah. Pada aspek kesalahan transformasi biasanya siswa mengalami kesalahan dalam menentukan rumus yang digunakan dalam menyelesaikan soal. Misal contoh pekerjaan siswa di bawah ini.

\section{Soal No 6}

Dalam sebuah pelambungan dadu sebanyak 120 kali, tercatat muncul mata dadu 5 sebanyak 18 kali dan muncul mata dadu 6 sebanyak 22 kali.

a. Tuliskan peluang teoretik dari kejadian tersebut.

b. Tuliskan peluang empirik dari kejadian tersebut.

c. Tuliskan hubungan antara peluang teoretik dengan pelang empirik.

Jawaban siswa pada soal nomor 6 dapat dilihat pada gambar 3 .

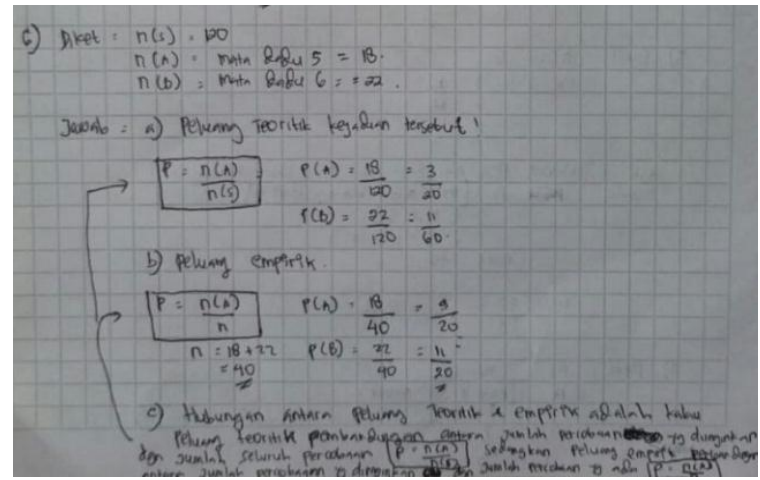

Gambar 3. Hasil Pekerjaan S3 
Dalam hal ini siswa telah mengetahui apa itu peluang. Akan tetapi siswa melakukan kesalahan dalam menentukan rumus. Siswa tidak memahami makna rumus peluang, yang seharusnya siswa dapat menyelesaikan pekerjaan menjadi jawaban yang benar. Berdasarkan hasil analisis pekerjaan S3, dapat dilihat bahwa S3 salah memilih angka pada soal nomor 6. Siswa masih bingung dalam menggunakan rumus yang dipakai dalam soal tersebut. Berdasarkan hasil analisis pekerjaan S3, dapat dilihat bahwa S3 salah dalam memilih angka yang digunakan pada soal nomor 6. Siswa tidak dapat memahami rumus yang digunakan pada soal. Ketidakpahaman S3 terjadi karena tidak paham dengan materi, masih bingung dengan perintah yang ada pada soal dan kurangnya latihan soal yang bervariasi tipenya.

\section{d. Kesalahan Keterampilan Proses (Processing Errors)}

Kesalahan proses disini yaitu kesalahan yang dilakukan oleh siswa dalam menyelesaikan soal cerita materi peluang ketika proses perhitungan. Pada tahap ini, siswa melakukan kesalahan dalam pengoperasian matematika seperti dalam penjumlahan, pengurangan, perkalian, dan pembagian. Misal contoh pekerjaan siswa di bawah ini.

\section{Soal No.3}

Dari 60 kali pelemparan sebuah dadu, diperoleh 13 kali muncul mata dadu 1, 12 kali muncul mata dadu 2, 15 kali muncul mata dadu 3, dan 8 kali muncul mata dadu 4. Tentukanlah frekuensi relative muncul mata dadu kurang dari 4.

Jawaban siswa pada soal nomer 3 dapat dilihat pada gambar 4

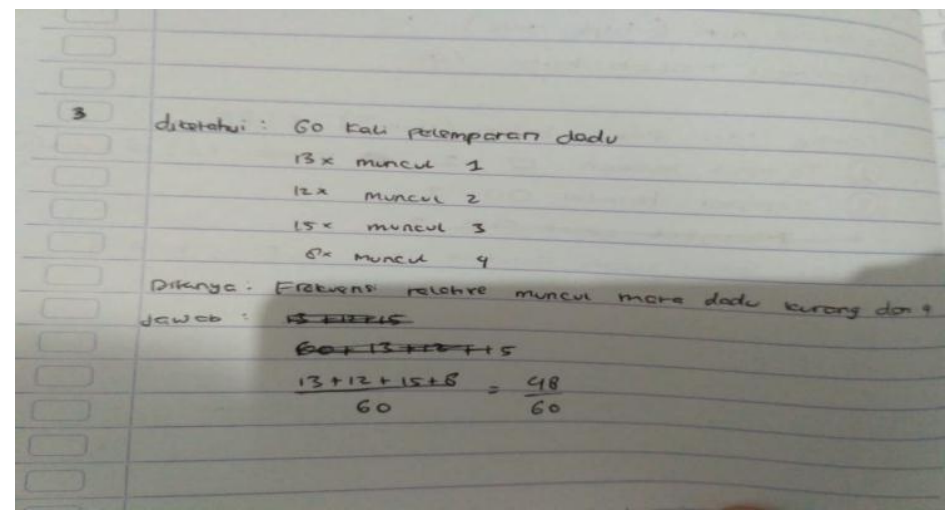

Gambar 4. Hasil Pekerjaan S4

Dalam hal ini siswa menjumlahkan semua angka yang diketahui dalam soal dan membaginya dengan banyak pelemparan dadu secara keseluruhan. Siswa melakukan kesalahan dengan tidak paham dengan peluang sehingga terjadi kesalahan dalam penyelesaian. Di awal pekerjaan S4 sudah benar, S4 melakukan kesalahan karena memasukkan jumlah muncul pada angka 4, sementara pada soal yang diminta adalah kurang dari 4. Siswa mengalami kesalahan dalam memasukkan total kejadian sehingga berpengaruh dengan hasil peluang kejadian. dapat dilihat bahwa S4 mengalami kesalahan dalam menghitung soal nomor 3.

\section{e. Kesalahan pada Notasi atau Penarikan Kesimpulan (Econding Errors)}

Pada kesalahan kesimpulan atau penulisan jawaban akhir, siswa memecahkan masalah dengan benar namun tidak bisa menyatakan solusi dalam suatu notasi yang tepat. Kesalahan yang terjadi adalah memeriksa jawaban dan mengaitkannya dengan permasalahan yang dinyatakan dalam soal cerita apakah memberikan pemecahan terhadap masalah semula. Misal contoh pekerjaan siswa di bawah ini. 


\section{Soal No.4}

Dalam sebuah permainan monopoli, 3 pemain menggunakan 2 dadu yang dilempar sekaligus. setiap pemain melempar dadu sebanyak 30 kali. Tentukanlah frekuensi harapan munculnya mata dadu kembar.

Jawaban siswa pada soal nomor 4 dapat dilihat pada gambar 6

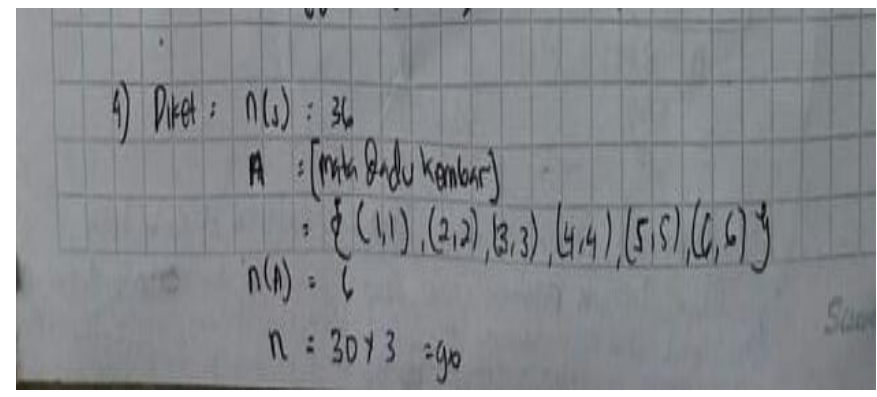

Gambar 6. Hasil Pekerjaan S5

Dalam hal ini siswa sudah paham dengan konsep ruang sampel pada pelemparan dadu dan munculnya mata dadu kembar. Akan tetapi dalam pekerjaan S5 terdapat kesalahan S5 harusnya menuliskan jawaban akhir serta kesimpulan. Oleh karena itu, konsep pengerjaan yang sudah tepat membuat S5 mendapat hasil perhitungan yang tepat pula didukung dengan ketelitian dalam perhitungan. Berdasarkan hasil analisis pekerjaan S5, dapat dilihat bahwa S5 melakukan kesalahan penarikan kesimpulan pada soal nomor 6.

Berdasarkan analisa data mengenai hasil pekerjaan siswa, peneliti memperoleh data mengenai jenis-jenis kesalahan siswa dalam menyelesaikan soal cerita materi peluang empirik dan teoretik. Diperkuat dengan hasil penelitian Pratama dan Ariyanto (2018) menyimpulkan bahwa tidak terdapat kesalahan pada tingkat membaca, tetapi kesalahan terbesar yang siswa lakukan adalah kesalahan pemahaman dan kesalahan transformasi, hal ini disebabkan karena kelemahan siswa dalam menguasai topik masalah. Wijaya dkk (2014) mengatakan sebagian besar kesalahan yang dilakukan siswa yaitu kesalahan pemahaman dan kesalahan transformasi, tuntutan kognitif merupakan faktor penting yang mempengaruhi kesalahan berdasarkan konteks, salah satu alasan yang mungkin adalah kurangnya latihan pada soal yang bervariasi.

Siswa yang melakukan kesalahan dalam langkah-langkah penyelesaian terjadi karena lemahnya daya ingat siswa dalam memahami dan menuliskan informasi yang terdapat pada soal kedalam rumus yang sesuai sehingga apabila terjadi kekeliruan dalam penulisan, kurang diketahui oleh siswa. Seperti hasil penelitian yang dilakukan Manibuy, Mardiyana, dan Saputro (2014) mengatakan bahwa proses memahami masalah sangat berpengaruh pada proses pemecahan masalah yaitu mengubah informasi pada soal dalam merencanakan dan membuat model matematika. Sebagian besar kesalahan siswa terjadi pada pemahaman serta di tingkat transformasi, kurangnya siswa dari pemahaman yang mendalam dari kosakata matematika, struktur semantik, dan tidak adanya hubungan antara bahasa formal siswa dan kemampuan matematika. Untuk itu perlu peran serta guru dalam membantu siswa untuk dapat melampaui tahap ini. Booth dkk (2014) menyimpulkan bahwa faktor yang sangat mempengaruhi kesulitan belajar siswa yakni kurangnya minat belajar siswa dalam matematika, kesulitan ini muncul dikarenakan pengajaran yang dilakukan guru tidak efektif dan kurang menyenangkan menjadikan siswa cepat bosan. Perlunya evaluasi dan penguatan terhadap guru pada materi yang diajarkan membantu siswa dalam mengoptimalkan hasil belajarnya.

\section{E. Simpulan}

Terdapat beberapa jenis kesalahan siswa kelas VIII SMP di Kabupaten Siak melakukan kesalahan dalam menyelesaikan soal cerita materi peluang empirik dan teoretik antara lain kesalahan dalam membaca soal, kesalahan dalam memahami makna soal, kesalahan dalam 
memilih transformasi untuk menyelesaikan permasalahan yang ada dalam soal, kesalahan proses pengerjaan dalam perhitungan, dan kesalahan dalam penulisan jawaban akhir. Kesalahan dalam membaca soal sebesar $15,15 \%$. Kesalahan dalam memahami makna soal sebesar 12,12\%. Kesalahan dalam memilih transformasi sebesar 12,12\%. Kesalahan dalam proses pengerjaan $1,52 \%$. Kesalahan dalam penulisan jawaban akhir sebesar $1,52 \%$.

\section{DAFTAR PUSTAKA}

Booth, J., Barbieri, C., Eyer, F. \& Paré-Blagoev, E. (2014). Persistent and pernicious errors in algebraic problem solving. Journal of Problem Solving, 7, 10-23.

Darminto, B.P. (2019). Analisis kesalahan mahasiswa dalam menyelesaikan soal sistem persamaan non-linear berdasarkan teori newman. Jurnal Prosiding Sendika, 5(1), 1-5.

Hidayatul, Laeli. (2017). Deskripsi kesalahan siswa kelas vii smp n 3 Kebasen dalam menyelesaikan soal operasi hitung bilangan bulat. Skripsi, Universitas Muhammadiyah Purwokerto.

Kurnia, L. \& Yuspriati, D.N. (2020). Analisis kesulitan siswa smp dalam menyelesaikan soal aritmatika sosial berdasarkan analisis newman. Jurnal Matematics Paedagogic, 6(2), 116-125.

Manibuy, R., Mardiyana, M., \& Saputro, D.R.S. (2014). Analisis kesalahan siswa dalam menyelesaikan soal persamaan kuadrat berdasarkan taksonomi solo pada kelas x sma negeri 1 plus di Kabupaten Nabire - Papua. Jurnal Elektronik Pembelajaran Matematika, 2(9), 933-945.

Mulyani, M. \& Muhtadi, D. (2019). Analisis kesalahan siswa dalam menyelesaikan soal trigonometri tipe higher order thinking skill ditinjau dari gender. JPPM (Jurnal Penelitian dan Pembelajaran Matematika, 12(1), 1-16.

Pratama, E.A. \& Ariyanto, A. (2018). Analisis kesalahan siswa dalam menyelesaikan soal bilangan berpangkat dan bentuk akar pada siswa kelas x smk muhammadiyah 2 Surakarta tahun ajar 2017/2018. Prosiding, Seminar Nasional Matematika dan Pendidikan Matematika 2018. Surakarta: Universitas Muhammadiyah Surakarta.

Rokhimah, S. (2015). Analisis kesalahan siswa dalam menyelesaikan soal cerita matematika materi aritmetika sosial kelas vii berdasarkan prosedur newman. Skripsi. Universitas Negeri Semarang.

Sari, L.N.I., Ferdiani, R.D., \& Yuwono, T. (2018). Analisis kesalahan dalam menyelesaikan soal cerita berdasarkan teori Newman. Jurnal Kependidikan Dasar Islam Berbasis Sains, 1(3), 99-106.

Sutisna. (2010). Analisis kesulitan menyelesaikan soal cerita matematika pada siswa kelas iv mi yapia parung Bogor. Skripsi. tidak dipublikasikan. UIN Syarif Hidayatulla Bogor.

Wibowo, Asmita Ratih. (2013). Pengaruh metode role play terhadap kemampuan menyelesaikan soal cerita. Tesis, tidak dipublikasikan. UIN Jakarta.

Wijaya, A., van den Heuvel-Panhuizen, M., Doorman, M., \& Robitzsch, A. (2014). Difficulties in solving context-based PISA mathematics tasks: An analysis of students' errors. The Mathematics Enthusiast, 11, 555-584.

Wilda Mahmudah. (2019). Analisis kesalahan siswa dalam menyelesaikan soal matematika bertipe hots berdasar Teori Newman. Jurnal UJMC, 4(1), 49-56. 